\title{
Plastic waste depolymerization as a source of energetic heating oils
}

\author{
Marta Wołosiewicz-Głąb ${ }^{1, *}$, Paulina Pięta $^{1}$, Sebastian Sas ${ }^{2}$, tukasz Grabowski ${ }^{1}$ \\ ${ }^{1}$ AGH - University of Science and Technology, Faculty of Mining and Geoengineering, Department \\ of Environmental Engineering and Mineral Processing, 30 A. Mickiewicz Ave., 30-059 Cracow, \\ Poland \\ ${ }^{2}$ AGH - University of Science and Technology, Faculty of Mining and Geoengineering, Department \\ of Underground Mining, 30 A. Mickiewicz Ave., 30-059 Cracow, Poland
}

\begin{abstract}
In the past years there has been an increase in production and consumption of plastics, which are widely used in many areas of life. Waste generated from this material are a challenge for the whole of society, regardless of awareness of sustainable development and its technological progress. Still the method of disposal of plastic waste are focused mainly on their storage and incineration, not using energy contained there. In this paper technology for plastic waste depolymerization with characteristics of fuel oil resulting in the process, as an alternative to traditional energy carriers such as: coal, fine coal or coke used in households will be presented. Oil has a high calorific value and no doubt could replace traditional solutions which use conventional energy sources. Furthermore, the fuel resulting from this process is sulfur-free and chemically pure. The paper presents the installation for plastics waste depolymerization used in selected Polish Institute of Plastics Processing, along with the ability to use the main thermocatalytic transformation product.
\end{abstract}

\section{Plastic waste's market analysis}

Over the last several years we have seen a steady increase in the production of plastics in the world, while in Europe, their production is stable and has remained at about 58 million Mg (Fig. 1). The largest producers of plastics are China, the US and Europe, and their share in world production was respectively $26 \%, 19 \%$ and $20 \%$ in 2014 .

The data indicate that the demand for plastics is increasing all the time. In Europe alone, in 2014 this value amounted to 47.8 million tonnes. Five European countries accounts for 2/3 of the consumption of plastic, which are: Germany, Italy, France, the United Kingdom and Spain. These numbers are reflected in the extensive use of plastics in many areas:

\footnotetext{
* Corresponding author: wolosiewiczm.@gmail.com
} 
as packaging, construction, agriculture, automotive and electronics industry, and many products like furniture, etc. [1].

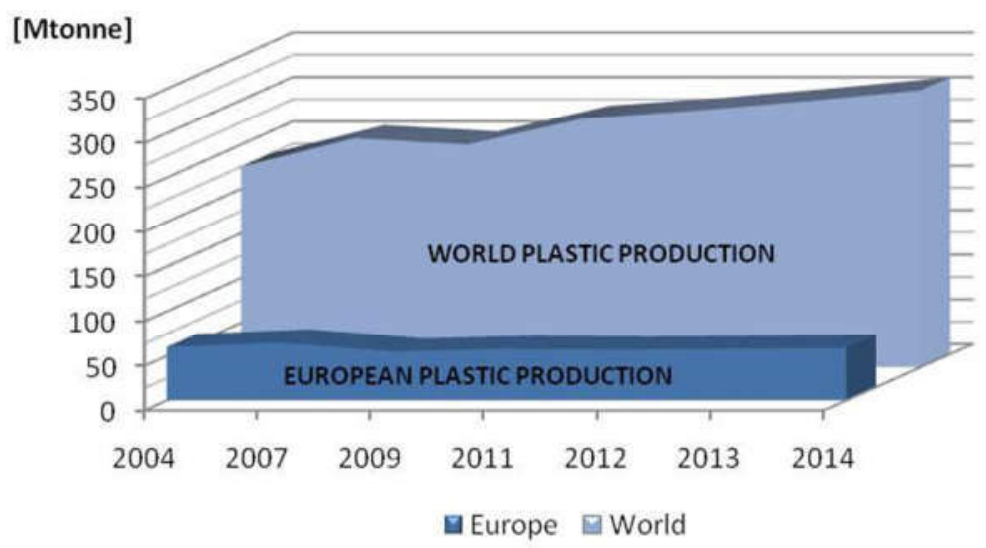

Figure 1. Plastic waste production in Europe and in the world for years 2004-2014. Source: [1]

The growing production of plastics affects the increase in the amount of waste generated and the need for their further development. An important assess direction of the plastic recycling process is the division due to their structural construction. The internal polymer structure, which are used for plastics production, determines their division into three groups: thermoplastics, thermosets and elastomers [2]. There are various types of plastics and their variations allow proper material selection for a particular application. The most commonly used plastics materials include polypropylene (PP), polyethylene (PE-LE and PE-HD), polyvinyl chloride (PVC), polystyrene (PS, EPS) and polyethylene terephthalate (PET), representing $72.8 \%$ of total demand in Europe [1]. In addition, in wastes we also find plastics listed in the table below.

Table 1. The types of plastics which can be found in waste. Source: [22]

\begin{tabular}{|c|c|c|c|c|c|}
\hline $\begin{array}{l}\text { Packaging } \\
\text { waste }\end{array}$ & $\begin{array}{c}\text { Construction } \\
\text { waste }\end{array}$ & $\begin{array}{c}\text { Agriculture } \\
\text { waste }\end{array}$ & $\begin{array}{c}\text { Waste } \\
\text { removed } \\
\text { from service }\end{array}$ & $\begin{array}{c}\text { Used } \\
\text { electrical and } \\
\text { electronic } \\
\text { equipment }\end{array}$ & $\begin{array}{c}\text { Mixed } \\
\text { municipal } \\
\text { waste }\end{array}$ \\
\hline \multicolumn{3}{|c|}{ LDPE } & \multicolumn{2}{|c|}{ ABS, PP, PA, PC/ABS } & \multirow[b]{3}{*}{$\begin{array}{l}\text { All kinds of } \\
\text { plastics can be } \\
\text { found }\end{array}$} \\
\hline & \multicolumn{2}{|c|}{ HDPE } & & & \\
\hline $\begin{array}{l}\text { PET, PP, } \\
\text { HDPE, PS, } \\
\text { PET-G, } \\
\text { SAN, } \\
\text { SMMA, } \\
\text { ASA }\end{array}$ & $\begin{array}{c}\text { EPS, XPS, } \\
\text { PUR, MDPE, } \\
\text { C-PCW, } \\
\text { PVDF, PPS, } \\
\text { PPSU, } \\
\text { PSU, PC, } \\
\text { PMMA, } \\
\text { ASA/PC, } \\
\text { ASA/PVC, } \\
\text { PVC }\end{array}$ & LLDPE, PP & $\begin{array}{c}\text { PC, PMMA, } \\
\text { POM, PBT, } \\
\text { PVC }\end{array}$ & $\begin{array}{l}\text { PS, PBT, PC, } \\
\text { POM, PMMA }\end{array}$ & \\
\hline
\end{tabular}

Disposal of waste from plastics is a challenge for society as a whole, regardless of awareness of sustainable development and technological progress. In 2014, postconsumer waste contained 25.8 million of used plastic, which $29.7 \%$ were recycled, the $39.5 \%$ were used for energy recovery, while the remaining $30.8 \%$ remained in landfills, which is equivalent to Europe losing by about 8 million tonnes of valuable raw material. However, when comparing the data for the years 2006-2014 for the disposal of plastic 
waste, trends are encouraging, because it significantly reduced the share of waste deposited at Europe's landfill sites (Fig. 2). European leaders in the recovery of waste plastics are Switzerland, Austria, the Netherlands, Germany, Sweden, Norway, Luxembourg, Denmark and Belgium. In these countries the storage prohibition was introduced, which means that landfill gets no more than $10 \%$ of such wastes. In Germany, Switzerland and the Netherlands is stored even less - only approx. $1 \%$ [1].

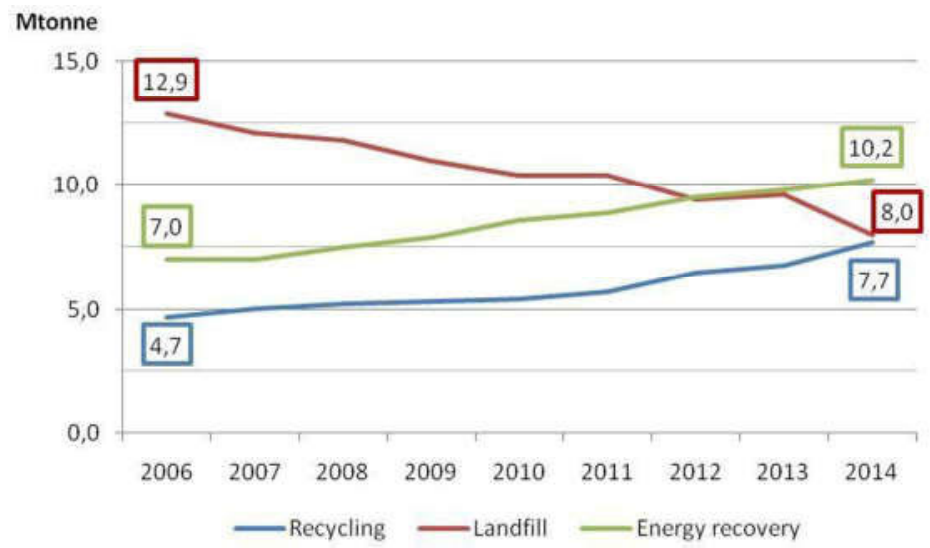

Figure 2. Total plastics waste recycling and recovery in the years 2006-2014. Source: [1]

Still, storage is present in many EU countries as the main way of plastics waste processing. Among the countries which stockpile of more than $50 \%$ post-consumer plastics waste are Hungary, Romania, Latvia, Croatia, Bulgaria, Greece, Cyprus, Malta and Poland.

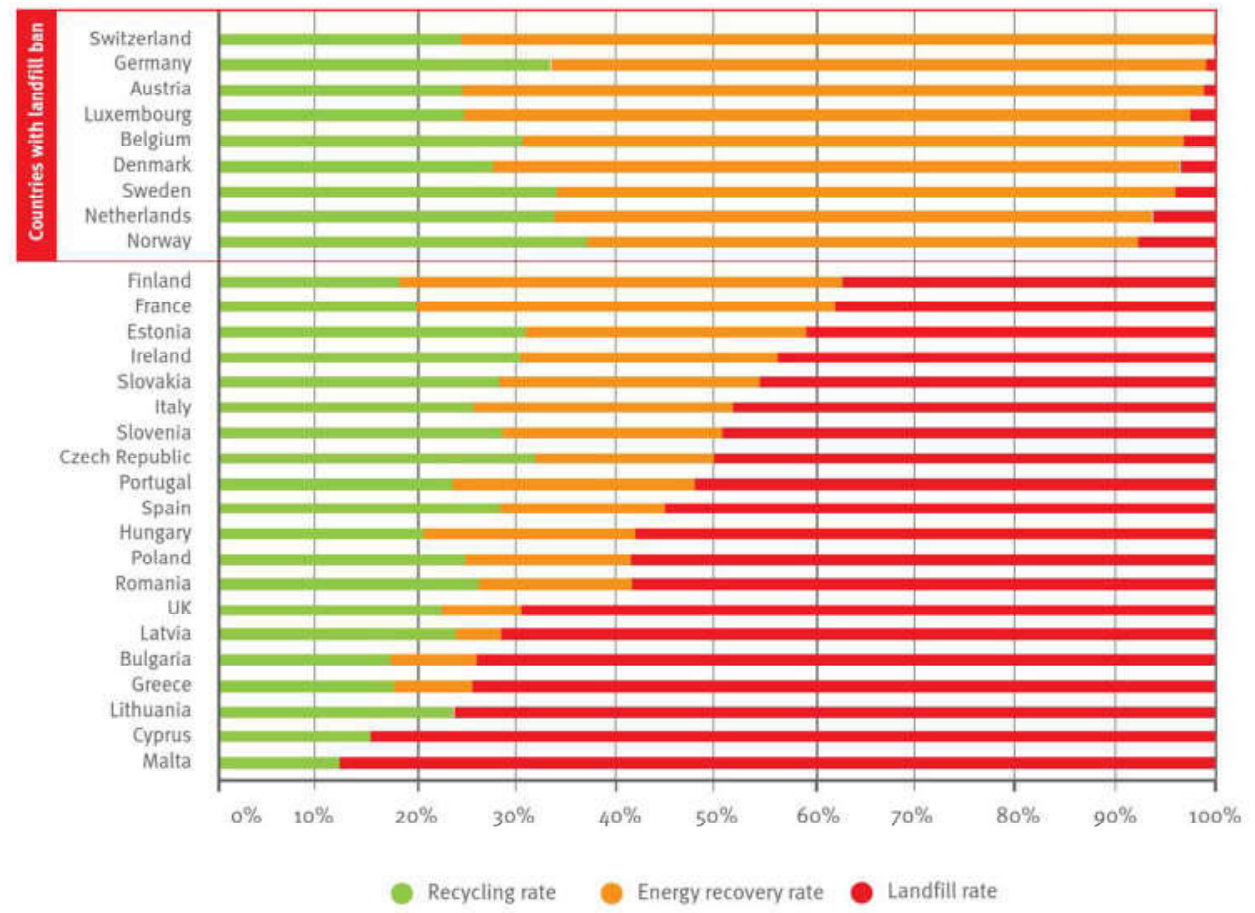

Figure 3. Treatment of post-consumer plastic waste in EU27 + 2 Source: [1] 
The economy of plastics waste in Poland in 2014 was as follows: 56\% was landfilled, $26 \%$ was recycled, and from $24 \%$ the energy was recovered [1]. A real opportunity to reduce the amount of plastic stored within large areas and degrading the environment and the landscape is a ban on the collection of plastic waste, as has been done in mentioned European countries. This initiative was introduced by the European Commission and described in the pages of the "Green Paper on plastics waste in the environment." According to the proposal the level of recycling of packaging waste in 2030 should increase to $80 \%$ and in the case of municipal waste - up to $70 \%$. However, in the longer term, EU countries should strive for the complete elimination of landfill of such waste [13].

\section{Plastics as an alternative energy source}

Alternative fuels can be both solid and liquid waste, municipal and industrial used as a replacement for conventional fuels. According to the definition, alternative fuel is such fuel which is obtained in the process of recovery of waste with a calorific value. Table 2 summarizes the most commonly used alternative fuels. Comparing of the mean values of the individual types of alternative fuel, it can be seen that lower calorific values are obtained for both the particulate solid fuels (18-23 MJ / kg), and the impregnated (8-11 MJ $/ \mathrm{kg}$ ). In contrast, a much higher calorific value is characterized by alternative liquid fuels (30-36 MJ / kg). Post-consumer plastics are among the waste with a high calorific value. Particularly interesting polymers in terms of calorific value are polyolefins, which can have up to $47 \mathrm{MJ} / \mathrm{kg}$, so that they can successfully compete with coal, coke or pulverized coal $[3,4]$.

Table 2. The calorific value of waste used as an alternative fuel. Source: [4]

\begin{tabular}{|l|c|}
\hline \multicolumn{1}{|c|}{ Alternative fuel } & Calorific value [MJ/kg] \\
\hline Used tires & 29,2 \\
\hline Plastics & $40-46$ \\
\hline Wastepaper & about 11 \\
\hline Used wood & about 18 \\
\hline Used solvents & about 25 \\
\hline Used rubber & 30 \\
\hline Used oils & 40 \\
\hline Municipal waste & $7-10$ \\
\hline Carbon slates & $12-18$ \\
\hline Coal sludge & $12-18$ \\
\hline Tar & 21 \\
\hline
\end{tabular}

Table 3. The calorific value of different fuels. Source: [5]

\begin{tabular}{|l|c|}
\hline \multicolumn{1}{|c|}{ Fuel } & Calorific value [MJ/kg] \\
\hline Coal & $25-28$ \\
\hline Wood & $7-14$ \\
\hline Heating oil & $40-48$ \\
\hline Polyethylene & 44 \\
\hline
\end{tabular}

Two trends dominate regarding to the disposal of plastic waste. The first is the landfill, and the second combustion. None of these typical solutions allows for complete utilization of the energy contained in this material. The production of solid alternative fuels from mixed waste is energy intensive process which makes it very expensive. In turn, the processing of waste in cement kilns does not allow full and swift recovery of their energy, and what is more, causing huge emissions dioxin, furans, nitrogen oxides and other substances. Harmful emissions into the atmosphere from the combustion of municipal 
waste causes huge degradation of the environment and constitutes a threat to the flora and fauna. In this situation, the best solution may be installations for depolymerization of plastic waste, enabling purification of the natural environment, maximum recovery and utilization of the energy contained in plastics.

\section{Polyolefins - a high-energy feed for depolymerization process}

Polyolefins (PE, PP) are the main group of synthetic plastics. These wastes due to mass scale production and their relatively uniform chemical composition are very attractive material for a variety of chemical transformation, undertaken in order to reduce the amount of them in landfills. The data provided by the Central Statistical Office indicate that polyethylene and polypropylene are the approx. $7 \%$ of municipal waste. In Poland, approx. $860000 \mathrm{Mg}$ polyolefins per year go to landfills.

PE waste has a high calorific value (Table 2) and can be used as fuel to produce electricity and heat. However, their burning faces some technical difficulties. Starting with a special dispenser, by adjusting the furnace combustion to change of state of the raw material. A major complication may also be mechanical impurities and heterogeneity of materials, which results in the need to introduce full automation of the operation of the furnace / burner $[5,6]$.

An interesting feature of polyolefins is their relatively easy breakdown (cracking) at elevated temperature. At a temperature of $400(450)^{\circ} \mathrm{C}-800{ }^{\circ} \mathrm{C}$ there is a rupture of chemical bonds and the formation of polymers of low molecular weight products which can be divided into 4 groups: gaseous products, liquid hydrocarbons, solid paraffin products and coke. Depending on the applied temperature for the cracking process the share of individual product groups changes (Fig. 4). Research has shown that as a result of the catalytic cracking at a temperature of $470^{\circ} \mathrm{C}$ it can be approx. $85 \%$ of the liquid product, $10 \%$ of non-condensable gaseous products and $5 \%$ of coke $[5,6]$.

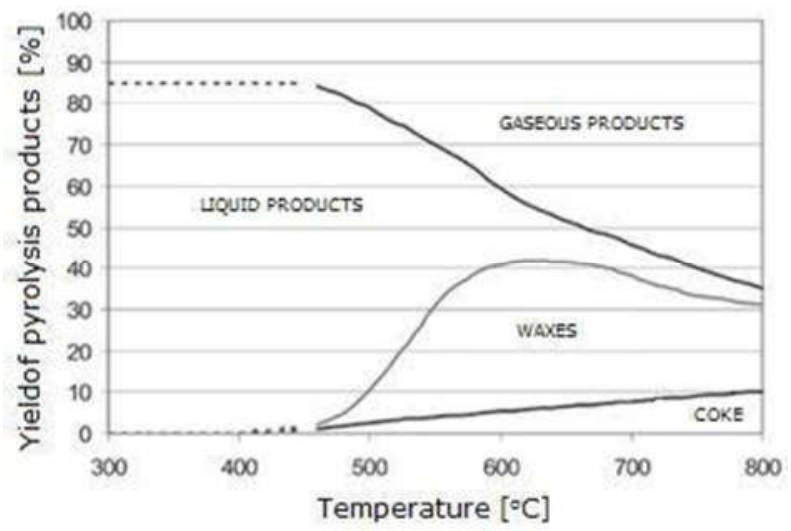

Figure 4. Approximate changes of polyolefins pyrolysis products depending on process temperature. Source: [5]

\section{Plastics depolymerization technology}

The most common method in the case of polyolefins' waste is the thermal cracking. It consists in subjecting the waste to high temperatures, typically in the range of 500$800^{\circ} \mathrm{C}$. The decomposition products include: solid carbonaceous residue and liquid hydrocarbons and the high calorific gas [9, 10]. BASF, Fuji Tech. Conrad., Hamburg 
Pyrolysis and BP have developed pyrolysis technology on fluidized layer [8, 12]. The disadvantage of this method is on the one hand the need for a high temperature and a large amount of waste products that require further processing steps, so that they can be used for e.g. as components for fuel. The advantage of pyrolysis of waste is that it is simple process from the technical point of view.

Competitive method compared to pyrolysis is catalytic cracking. It allows thanks to the selection of suitable catalysts to control, within certain limits, both performance and distribution of the products of degradation of polymers, as well as lower the temperature of the process, which is a big advantage. Zeolites are used as catalysts in the form of particulate matter. Catalytic cracking of plastics waste on an industrial scale has been implemented by Nippon Steel Corporation (Japan) [9, 11]. The diagram of the plastic depolymerization system is presented in Fig. 5.

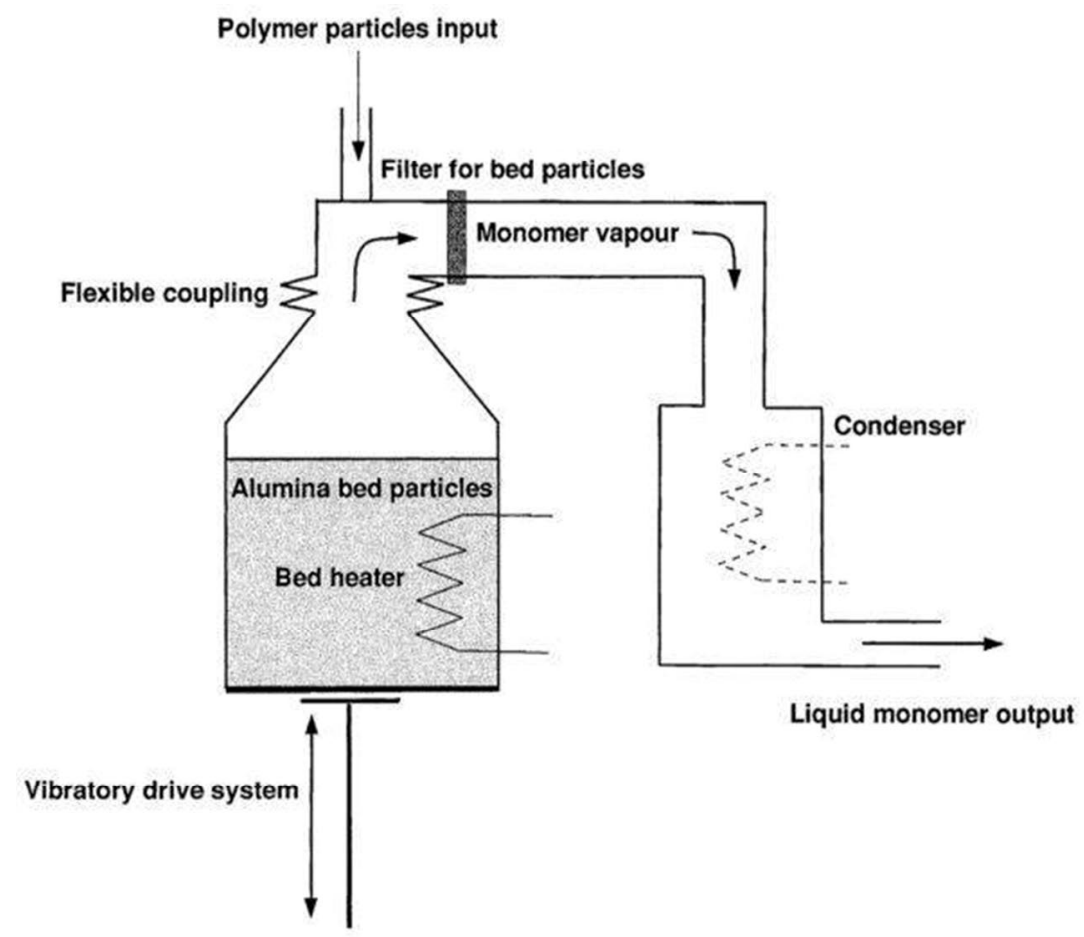

Figure 5. Schematic representation of a mechanically fluidised depolymerisation process. Source: [21]

During the catalytic cracking of a polyolefin heating is carried out at temperatures of $380-480^{\circ} \mathrm{C}$, which results in progressive cracking of the polymer chains to hydrocarbon molecules formed by a low boiling point. The vapour-gas phase consists of gaseous hydrocarbons (methane, ethane, ethylene, propane, isopropylene, etc.). Products condensing in room conditions are liquids, including gasoline and oil fraction. With these fractions the paraffins are also distilled off which, although can not be separated, they have the tendency to slowly crystallize and precipitate as a sediment. The fusion of the starting waste is not easy, since polyolefins have a low coefficient of thermal conductivity, and after melting initially have the form of a very viscous liquid [5, 14]. For supporting the endothermic cracking reaction catalysts may be used provided in the system discussed in the next section. The use of cracking catalysts improves the heat transfer from the heated waste and lowers the cracking temperature and reaction products achieve greater uniformity 
of quality. Most catalysts are mixtures of zeolite, kaolin, or quartz. Studies [6] showed that the course of the depolymerization is influenced by the method of catalysts application. Additionally, what it is very important, catalytic process of polyolefins thermodegradation occurs with $100 \%$ relative efficiency and hence of $100 \%$ pure yield.

Plastics processing is a rapidly developing field of science because of the importance and the global incidence of these materials. Numerous studies and publications, and continually introduced new solutions confirms the dynamic development of this area of knowledge. Interesting technological solutions have been presented in the work for providing heat to the PE waste in liquid metal reactors [18], fluidized layer reactors [19, 20], or by hot gas, which is a heat transfer medium [16]. Difficulty in giving heat to melted and heated polymer and difficulties in swaging the melted polymer due to its high viscosity and the possibility of solidification, inspired research to develop techniques of cracking in an aqueous medium [17]. Heat supply supporting the pyrolysis reaction using infrared radiant heaters is proposed in [19]. Another heating technique is the use of electromagnetic waves with a frequency of $2450 \mathrm{MHz}$ and an ultrasound for the reaction of cracking of various waste, including polymers. A potential pre-irradiation of waste polyethylene with gamma irradiation to induce a preliminary degradation of chemical chains facilitate the following thermal degradation [5].

\section{Characteristics of the technological system}

The work describes technology of processing of plastics waste both polyethylene and polypropylene in the hydrocarbon mixture of paraffins and olefins in the way nonpressure catalytic cracking on the example of Polish installations of the Plastics Processing [14]. The task of the processing line is to process plastics to obtain fuel component. In the case of the depolymerization process the raw materials of PP and PE can be mixed in any proportions. Impurities are acceptable, such as: sand and dust, printed labels on the packaging. Plastics may have a different colour. Importantly, the waste must meet certain quality requirements. It is necessary that it is uniform in terms of the type of materials and can not include organic admixtures containing $\mathrm{Cl}, \mathrm{N}, \mathrm{S}$ or carbonyl groups, as well as wood, stone, and metal. The maximum moisture content should not exceed $10 \%$, and the pollution can not have a larger share than $5 \%$ of the total charge weight. Processing capacity of installation is set at $1,460 \mathrm{Mg} /$ year in cyclical work.

In the first cycle of the process of transformation the polyolefin recyclable materials are shredded into few millimetres fraction. However, research carried out at the Warsaw University of Technology showed that optimal yields of liquid fractions are obtained by granulation of the feed material of $0,063-0,071 \mathrm{~mm}$ or $0,08-0,1 \mathrm{~mm}$ [6]. The prepared material is collected in the retention tank and mixed with the catalyst ( $\mathrm{Al} / \mathrm{Al} 2 \mathrm{O} 3$ ). A conveyor belt continuously supplies a material to a reactor equipped with suitable systems for monitoring and controlling. Catalytic cracking process takes place at a temperature of $420^{\circ} \mathrm{C}\left( \pm 10^{\circ} \mathrm{C}\right)$ with separation of hydrocarbon fraction from $\mathrm{C} 1$ to $\mathrm{C} 34$. Heat essential to the process is supplied from the combustion of light fuel oil in a burner with a capacity of approx. $100 \mathrm{~kW}$ and the burner from the combustion of an uncondensed gaseous fraction. Because of the continued supply of polyolefins in the reaction chamber reaction mass is formed, which is mixed with the anchor stirrers. The next step is to direct the hydrocarbon mixture to the distillation system, where the separation of the ingredients occurs by evaporation and condensation in the cooler with air cooling and an aqueous medium. Gas fractions $\left(C_{1}\right.$ to $\left.C_{4}\right)$ flow into the intermediate tank, from which are collected by the gas burners of the reactor to heat the next batch of feed material. While the liquid fraction $\left(\mathrm{C}_{5}\right.$ to $\left.\mathrm{C}_{34}\right)$ at approx. $20^{\circ} \mathrm{C}$ flows to the storage tank which is heated by the heat received from the coolant in the distillation system. 
The use of high-energy gaseous products of polyolefins depolymerization and cooling system significantly improves the economics of raw material thermocatalysis. The applied technology was not equipped with an automatic cleaning system, and therefore impurities are removed periodically [14]. The system is equipped with two reactors, while the second one of them is cleaned from unprocessed impurities, the first works. Schematic of this circuit is shown in Fig. 6.

The final product of the processing of raw material is a mixture of saturated hydrocarbons. The resulting combination of hydrocarbons $\mathrm{C}_{5}-\mathrm{C}_{34}$ due to the applied technology of evaporation is chemically pure. The resulting liquid fraction can be used as a raw material in the refining and petrochemical industry, or may be treated as a starting material in other branches of chemical industries for the production of chemical products from PE and PP. Another application is to use the mixture as a synthetic fuel.

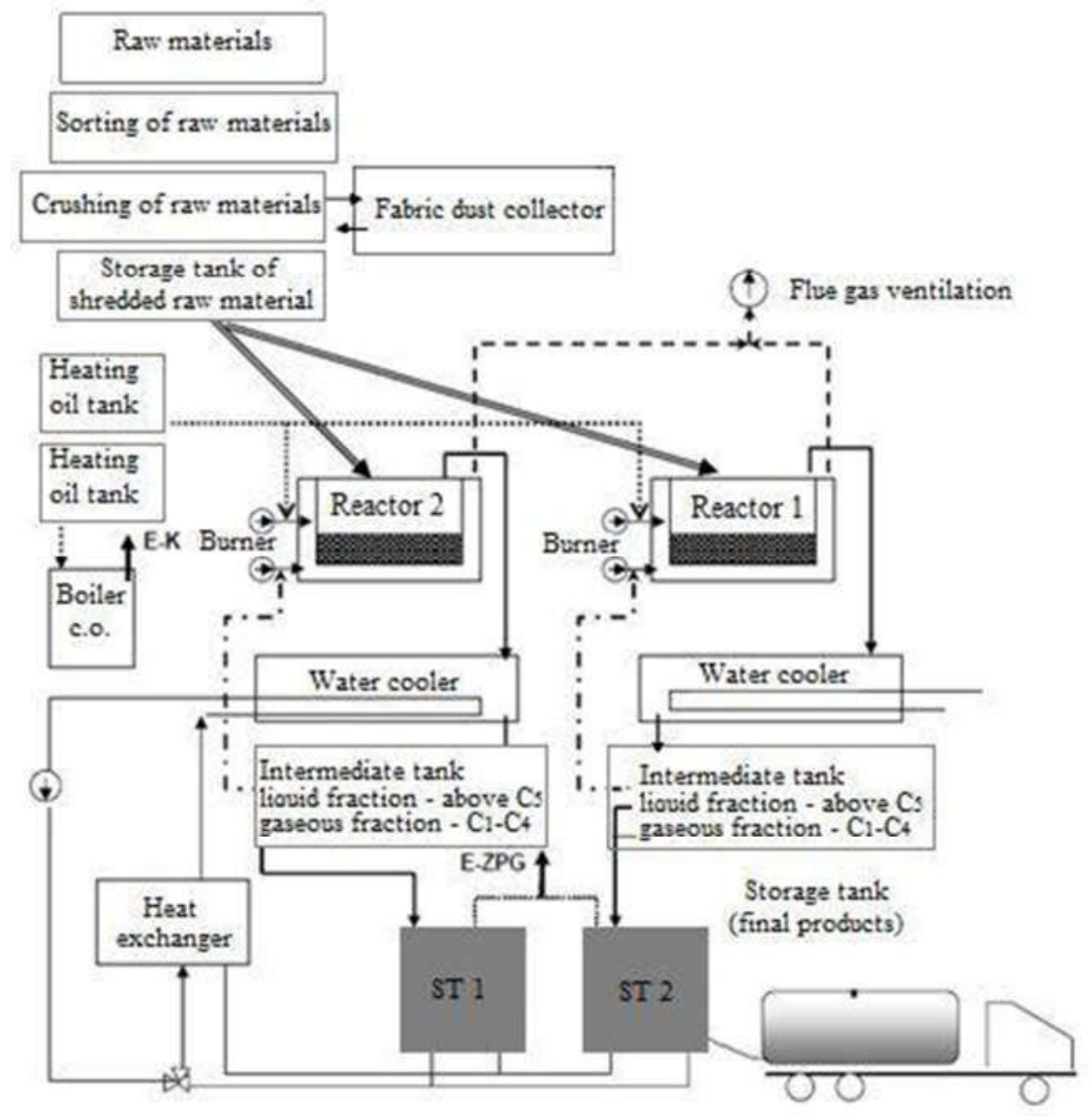

Figure 6. Scheme of the technological system for catalytic plastic material depolymerization. Source: [14]

\section{Conclusions}

Depolymerization technology involves the conversion of this type of raw material for liquid energy carriers (oil, fuel oil), while the use of process gas generated during the recycling process. Furthermore, the fuel resulting from this process are sulfur-free and chemically pure. Characterized in that they are ready-to-use and capable of storage and transport. At the same time the performance of the plastics depolymerization module 
can easily be adapted to the size and type of supplies. In $80-85 \%$, these installations allow the recovery of the energy contained in the plastic waste. Approximately $11 \%$ is the process gas, which is a carrier of energy for operation, and the waste of coke breeze (4-9\%), depending on the amount of impurities contained in the device with the target material. Depolymerization products of $1 \mathrm{Mg}$ of mixed plastics are energy carrier between 4.5 and 5.9 MWe net and up to 5 MWt net. Process energy consumption is small - 0.8-1 $\mathrm{kWh} / \mathrm{kg}$, and more importantly this energy can be directly supplied from products resulting from the operation of the system. Admittedly, it can be concluded that the technology for the conversion of plastic into alternative fuels is characterized by high efficiency and is environmentally friendly.

To sum up, the technology of plastics depolymerization is an environment-friendly process, creating the possibility for safe and effective reduction of a part of the waste from the group of olefins by converting them into products of commercial applications. Used during the process PE and PP products do not meet the requirements that would allow their recycling, thus subjecting them to thermocatalytic conversion in energy products is the best ultimatum for the collection of these substances in landfills, which has more negative impact on the environment than the mentioned process of depolymerization. The biggest advantage of plastics processing plant are final products which can be widely used in various industries (refinery and petrochemical industry, production of household chemicals, energy industry for the production of gaseous and liquid). In addition, thanks to the process of depolymerization, we can limit environmental degradation as a result of depositing waste, proceeding in accordance with the waste hierarchy referred to in the Act on Waste, and closing the life cycle of waste by recycling them. In addition, a significant part of the work of the high temperature thermal cracking is the process temperature which is qualified as a medium temperature heat source. The energy in the process can be used as a source of energy (by using a recuperation process) to carry out other processes on the premises, or be used as an energy source for the process water or hot water installation for the social purposes. In case of described process, the ecological effect has been achieved simultaneously with economic effect, which is the greatest achievement of this technology.

\section{Acknowledgement}

The paper is the effect of the scientific project no. 15.11.100.021.

\section{References}

1. Plastics Europe. Plastics - the Facts 2014, An analysis of European latest plastics production, demand and waste data (2015)

2. Mróż J., Recykling i utylizacja materiałów odpadowych w agregatach metalurgicznych. Wyd. Pol. Cz., Częstochowa (2006)

3. Sorek A., Borecki M., Ostrowska-Popielska P., Selected plastic waste as a source of alternative fuels in the metallurgical industry, IMŻ, vol. 4, pp. 47-57 (2012)

4. Walendziewski J., Kałużyński M., Surma A., Sieć Naukowo-Gospodarcza "Energia" Określenie potencjału odpadów i ich rodzaju do produkcji stałych paliw alternatywnych, projekt Z/2.02/II/2.6/06/05, Wrocław (2007)

5. Grzybowski P., Transformation of the poliethylene wastes into fuel products, Chemik, 66, 7, 725-734 (2012)

6. Sokołowski J., Rokicki G., Marczewski M., Szewczyk K., Thermalcatalytic recycling of polyolefins and polystyrene. CzT Ch, 16, 2, 311-321 (2008) 
7. Sokołowski J., Sposób termiczno-katalitycznego recyklingu składników polimerowych obejmujących poliolefiny i polistyren oraz przepracowanych olejów silnikowych w obecności ditlenku węgla oraz instalacja do realizacji sposobu. Patent PL 216345 B1 (2013)

8. Belgiorno V., De Feo G., Della Rocca C, Napoli R.M.A. Waste Manag., 23, 1 (2003)

9. Aguado J., Serrano D.P., Feedstock Recycling of Plastic Wastes (Ed. J.H.Clarc), The Royal Society of Chemistry, Cambridge (1999)

10. Tukker A., Plastic waste Feedstock Recycling, Chemical recycling and Incineration, Rapra Review Reports, 3(4), Report 148, Rapra Technology Ltd., Shropshire, United Kingdom (2002)

11. EPA SITE Technology Capsule, Texaco Gasification Process, Environmental Protection Agency, Office of Research and development, Cincinnati, OH45268EPA540/R94/515a[on line] [access: 25.08.2016] At the following website: http://www.epa.gov/ORD/SITE/reports/540r94514/540r945a.pdf (1995)

12. Metecan H., Ozkan A.R., Iskr R., Yanik J., Saglam M., Yuskel M., Fuel, 84, 30619 (2005)

13. Saj E., Unia szykuje całkowity zakaz składowania tworzyw sztucznych [online],[Access: 25.08.2016] At the following website: http://www.srodowisko.abc.com.pl/czytaj/-/artykul/unia-szykuje-calkowity-zakazskladowania-tworzyw-sztucznych (2015)

14. Pracownia B-B Projektowo-Usługowa Zdzisław Budych. Raport o oddziaływaniu na środowisko planowanego przedsięwzięcia - Zakładu Przetwórstwa Tworzyw Sztucznych w Szwecji k. Wałcza (2012)

15. Nolte M. J., Zięba A.: Sposób i układ do prowadzenia krakingu odpadów poliolefinowych. Patent PL 351703 (2002)

16. Charles W. et al.: Cracking Process. Patent US 3,985,820, (1976).

17. Hughes W.L. et al.: Method of converting organic material into useful productsand disposable waste. Patent US 4,657,681 (1987)

18. Tatsumi T., et al.: Process for the thermal decomposition of thermoplastic resinswith a heat transfer medium. Patent US 3,974,206 (1976)

19. Kirkwood K.C., et al.: Polymer cracking. Patent US 5,364,995 (1994)

20. Fan L. et al.: Pyrolitic conversion of carbonaceous solids to fuel gas in quartzsand fluidized beds. Patent US 4,448,589 (1984)

21. Newborough M., Highgate D., Vaughan P.,Thermal depolymerisation of scrap polymers, Appl. Therm. Eng., 22, 17, 1875-1883 92002)

22. Borkowski K.., The recycling of plastics, PlasticsEurope Fundation, Poland [on line], [access: 26.08.2016] At the following website: www.pie.pl/materialy/_upload/KONF_OPAK/PlasticsEurope_KBorkowski.pdf (2015) 